\title{
NOTICING US AND THEM CONSTRUCTIONS: THE PEDAGOGICAL IMPLICATIONS OF A CRITICAL DISCOURSE ANALYSIS OF REFERRING IN POLITICAL DISCOURSE
}

\author{
Susan Brokensha \\ University of the Free State
}

In the past decade, there have been a number of discourse analyses of the political in South Africa such as Botha's (2001) study of deictic expressions in a speech by Thabo Mbeki, Moodley's (2006) discursive analysis of the South African government's Information and Communication Technologies, poverty, and development discourse, and Moon's (2006) investigation into the discursive construction of narratives generated during the Truth and Reconciliation Commission. However, how such studies may be exploited to foster students' critical thinking about language use in a variety of communicative contexts has not been explored in much detail. Within the framework of Critical Discourse Analysis (CDA), the aim of this paper is to examine the phenomenon of referring in a political speech by Robert Mugabe, focusing specifically on his use of spatial, temporal, and social indexicals to construct us versus them territories. Next, the constructivist principles that may be adopted to assist second-year Linguistics students in developing an awareness that referring is not a neutral phenomenon are identified.

\section{INTRODUCTION}

\subsection{CDA, political discourse, and pedagogy}

As will become clear in this paper, Critical Discourse Analysis (or CDA) has become a highly effective research tool for the analysis of spoken or written discourse as it is regarded as 'an established force in academia' (cf. De Beaugrande, 2006: 29), drawing on disciplines that run the gamut from communication sciences and linguistics to anthropology and economic sociology. And this despite one of its major drawbacks, which entails the fact that it is difficult, theoretically speaking, to 'ground' CDA, given its eclectic theories and methodologies (cf. Henderson, 2005: 9; Poole, 2010: 151). In the field of education, language practitioners have begun to recognise the value of CDA as a tool to equip students with the skills to critically engage with discourse settings that include classrooms, courtrooms, and political news interviews. Although CDA has come into its own in education, a key pedagogical problem remains: How does one teach undergraduate students to analyse and critique texts within the framework of CDA, particularly when they may lack sophisticated analytical skills? Having an abiding interest in discourse analysis and in teaching students how to reflect on and interpret texts, one of the aims of this paper's author is to show how a CDA study may be exploited to foster second-year Linguistics students' critical thinking 
about the notion of referring in political speeches. First, however, a closer look is taken at the use of CDA in institutional contexts.

\subsection{CDA in institutional contexts}

Since the publication of such seminal books as Teun van Dijk's (1984) Prejudice in discourse, Norman Fairclough's (1989) Language and power, and Ruth Wodak's (1989) Language, power and ideology, CDA has emerged as a significant and established paradigm of research within Linguistics. It has been used to study diverse institutional contexts such as teacher talk in the classroom (Hanrahan, 2005), newspaper language (Izadi \& Saghaye-Biria, 2007), television interviews (Chase, 2008), medical student discourse (Basu \& Roberts, 2009), and strategy texts within organisations (Vaara, Sorsa \& Pälli, 2010).

In view of the fact that ' $\mathrm{CDA}$ is a problem oriented and trans-disciplinary theory and method' (Rogers, 2008: 53) that endeavours to expose how the abuse of power and inequality, for example, are constructed through language, it is not surprising that researchers across the globe have come to recognise the educational value of CDA. For instance, Thornton and Reynolds (2006) have employed this analytical framework to investigate the notion of student agency in a mathematics classroom, while Dieter (2007) has applied it to asynchronous interaction with a view to determining how adult learning takes place in an online environment. Other educational contexts in which CDA has proved useful range from English as a Foreign Language (Hammond, 2006; Tanaka, 2006) and English for Academic Purposes (Morgan, 2009) to racial literacy (Rogers \& Mosley, 2006; 2008) and drug education aimed at high-school learners (Tupper, 2008).

In recent years, South African educational researchers too have turned to CDA to investigate the relationships between language and society in a variety of discourse contexts that include student beliefs about diversity (Janks, 1999), curriculum restructuring in higher education (Ensor, 2004), academic literacy in second-language classrooms (Kapp, 2004), anonymous online interactions among university students (Ng'ambi, 2008), and asymmetrical power structures reflected in HIV/AIDS media campaigns (Aulette-Root, 2010).

There have also been discourse analyses of the political in South Africa such as Moodley's (2006) discursive analysis of the South African government's Information and Communication Technologies, poverty and development discourse and Moon's (2006) investigation into the discursive construction of narratives generated during the Truth and Reconciliation Commission. However, with the exception of analyses by researchers such as Chigona, Mjali and Denzil (2007), Chigona, Pollock and Roode (2009), and Ndambuki and Janks (2010), there have been few CDA-based studies of political discourse in Africa and even fewer discourse studies that deal with the notion of referring in African political discourse - only Botha's (2001) study of person deixis in a speech by Thabo Mbeki and Adetunji's (2006) analysis of deixis in Olusegun Obasanjo's speeches come to mind. For this reason, and within the framework of CDA, the current paper explores a speech by President Robert Mugabe of Zimbabwe, showing how he makes use of referring to create an 'us'/'them' dichotomy between Africans and Westerners. Given that the focus is on functional aspects of language rather than on syntactic structure, the CDA framework used is informed by systemic functional grammar (Halliday \& Matthiessen, 2004). 


\section{FRAMEWORKS OF ANALYSIS}

Below, the frameworks of analysis - critical discourse analysis and membership categorisation - are briefly discussed. The rationale for this methodological synergy comes from Baker (2000: 99), who contends that 'categories and categorisation work lock discourses into place, and are therefore ready for opening to critical examination'.

\subsection{Critical Discourse Analysis (CDA)}

As already mentioned, one of the aims of this paper is to examine how the phenomenon of referring is used in political speeches to delineate 'us' versus 'them' positions. Specifically, the focus is on deixis which allows a politician to either include or exclude certain groups from his or her so-called deictic centre, which incorporates, amongst other elements, the speaker's present time, social status, and physical location (cf. Rooryck \& vandenWyngaerd, 2007: 34). Since politicians "may intentionally impose boundaries demarcating "us" and "them" territories' (Wieczorek, 2009: 118) that reflect, for instance 'Our good things' and 'Their bad things' (Van Dijk, 2006: 359) respectively, discursive manipulation comes into play. CDA is regarded as an appropriate research tool to study this kind of manipulation, since 'most manipulation, as we understand this notion, takes place by text and talk' (Van Dijk, 2006: 260). ${ }^{1}$ Because CDA views discourse as a form of social action that is shaped by power and ideology, it is a powerful analytical tool for revealing (hidden) agendas, motives, and beliefs. A detailed discussion of CDA falls beyond the scope of this paper, but its other major tenets, based essentially on those outlined by Fairclough and Wodak (1997: 271-280), may be summarised as follows:

- First, CDA regards power relations as discursive and explains how these relations are created and sustained through discourse. For example, discursive practices may serve as vehicles to construct asymmetrical relations between ethnic minorities and majorities, or between men and women.

- Second, CDA takes social problems into account: 'The intention of the analyst...is explicitly oriented toward locating social problems and [analysing] how discourse operates to construct... such issues' (Rogers, 2004: 4). For instance, a recent CDA-based study by Wirgau, Farley and Jensen (2010) has examined how so-called 'consumption philanthropy' - connecting brands to charitable causes - impacts on social change.

- Third, discourse is historical in that a text can only be understood in terms of its context, time, and place (cf. Wodak, 2001: 3). Wodak (2009), for example, has employed a critical discourse-historical approach in her study of racism.

- $\quad$ Finally, discourse, society and cognition are linked (cf. Van Dijk, 2006: 360). Put a little differently, discourse and society are mediated by social cognition (cf. Hart, 2008a: 92).

\subsection{Membership Categorisation Analysis (MCA)}

Although rooted in CDA, this paper also employs elements from membership categorisation analysis (MCA) to study the phenomenon of referring in political discourse. Originating from

\footnotetext{
${ }^{1}$ Discourse structures themselves are not manipulative: 'they only have such functions or effects in specific communicative situations and the way in which these are interpreted by participants in their context models' (van Dijk, 2006: 372).
} 
the work of Sacks $(1972 ; 1992 a ; 1992 b)$ and expanded upon by a number of researchers (notably Hester \& Eglin, 1997; Leudar \& Nekvapil, 2000; Leudar, Marsland \& Nekvapil, 2004; and Schegloff, 2007), MCA studies how people employ social categories - membership categorisation devices or labels - to organise themselves into specific groups that reflect their identities (cf. Zimmerman, 2007: 72). Thus, for instance, the categories 'lieutenant', 'captain', and 'major' fall under the membership categorisation device, 'SAPS (South African Police Service) rank system', while 'child', 'mother', and 'father' belong to the membership categorisation device 'family'.

Traditional MCA has tended to focus on fixed categories that pertain to gender (Eglin, 2002; Stokoe, 2003) and family relations (Summerfield \& McHoul, 2005; Butler, 2006), but in recent years, several researchers interested in critical approaches to language have integrated MCA into CDA (Johnson, 2002; Johnson \& Stevens, 2002; Meadows, 2007; Bhatia, 2009). Although MCA is an unusual approach to analyse 'us' and 'them' as membership categories (cf. Leudar et al., 2004), Meadows (2007: 4) points out that it is an 'innovative application' that allows one to examine how us-them polarisation is socially constructed in political discourse, hence its adoption in this paper to study a speech delivered by Robert Mugabe.

It should be noted that it is not the author's aim to take sides or to prove that either the West or Africa is 'right' or 'wrong'. Instead, it is the author's intention to show how a discoursebased analysis 'can help us understand not just what [texts] mean, but how they mean' (Haig, 2001: 206).

\section{ANALYSES}

\subsection{Distanciation}

The speech in question is one that Robert Mugabe delivered on 26 September, 2007, on the occasion of the 62nd session of the United Nations (UN) General Assembly in New York. One of the agenda items for discussion was the promotion of peace and sustainable development in Africa, and in addressing this issue, Mugabe frequently attacked the West for '[behaving] like bullies, trampling on the rights of weak and smaller states...' (Mugabe address 26/09/2007 - Paragraph 6) such as those located in Africa and the Middle East.

Typically, political discourse is constructed around the deictic centre which, as mentioned earlier, comprises the speaker's specific location in time and space, as well as his or her particular position in a given social hierarchy (cf. McIntyre, 2006: 92-93). It is not surprising that politicians generally locate themselves inside the deictic centre and place other discourse elements such as their audiences either inside or outside it. According to Wieczorek (2009: 120), the various discourse elements - whether inside or outside the deictic centre - are located along three axes that emanate from the centre. These axes encompass the spatial, temporal, and axiological axes. The first dimension has to do with discourse elements occupying a specific physical or geopolitical location, while the second entails discourse elements being positioned according to their historical location. Finally, the axiological axis has to do with discourse elements being located according to their values and ideological beliefs (Wieczorek, 2009: 120; cf. Adetunji, 2006: 181). Consider, for example, the excerpt below. 
Mugabe address 26/09/2007 - Paragraph 5

Climate change is one of the most pressing global issues of our time. Its negative impact is greatest in developing countries, particularly those on the African continent. We believe that if the international community is going to seriously address the challenges of climate change, then we need to get our priorities right. In Zimbabwe, the effects of climate change have become evident in the past decade as we have witnessed increased and recurrent droughts as well as occasional floods, leading to enormous humanitarian challenges.

In this example, the deictic centre consists of Mugabe at the time (26 September, 2007) and place (New York) of the address to the UN General Assembly. At the same time, people living 'in developing countries' as well as those 'on the African continent' and 'in Zimbabwe' are also positioned in the spatial dimension inside of the deictic centre. By contrast, and by implication, the West (or 'the Other') is located in the spatial dimension outside of the deictic centre - 'at the remote end of $s$ [the spatial axis]...' (Chilton, 2004: 58). This kind of positioning is no coincidence; by locating himself and those living in Africa or other emerging economies inside of the deictic centre and the West outside of the centre, Mugabe establishes unity with fellow Africans and developing nations. The repeated use of the inclusive 'we' also serves to enhance the solidarity relation between Mugabe and the addressees (cf. Chilton \& Schäffner, 2002: 30), as well as to convey the message that, in contrast to the West, developing nations have been hardest hit by climate change. Another example of how elements are arranged along the $s$ axis is illustrated in excerpt (2).

\begin{abstract}
Mugabe address 26/09/2007 - Paragraph 10
Zimbabwe won its independence on 18th April, 1980, after a protracted war against British colonial imperialism which denied us human rights and democracy. That colonial system which suppressed and oppressed us enjoyed the support of many countries of the West who were signatories to the UN Universal Declaration of Human Rights.
\end{abstract}

Here, entities are located along the spatial axis in such a way that Zimbabwe (reflected in the use of 'Zimbabwe' and the pronoun 'us') is once again at the deictic centre, while the other discourse elements - 'British colonial imperialism', 'that colonial system', and 'many countries of the West' - are situated at the opposite end of the $s$ axis to create a dichotomy between the Zimbabweans and the British/Westerners.

In the same excerpt, historical events, namely Zimbabwe's celebration of independence in 1980 and its war against British colonialism, are positioned along the temporal or $t$ axis at a distance from the deictic centre. Hart (2008b: 119) rightly observes that 'a historic event may be positioned "closer" to [the] deictic centre in order to make it more salient'. Thus, in the given example, Zimbabwe's independence is in closer proximity to the deictic centre, whereas Zimbabwe's struggle for freedom (reflected in the words 'after a protracted war against British colonial imperialism' and 'that colonial system which suppressed and oppressed us') is positioned at a comparative distance from the centre in order to show that some time has elapsed between the war and independence - what Wieczorek (2009: 125) refers to as 'a receding past'.

The axiological dimension reflects the speaker's ideological beliefs as opposed to those of 'the Other' (cf. Cap, 2008: 38) and, in the above excerpt, it is apparent that Mugabe aligns 
himself with fellow Zimbabweans' struggle for 'human rights and democracy', while Westerners and particularly the British are identified with 'colonial imperialism' which 'suppressed and oppressed' Zimbabweans in the past. Mugabe's use of 'Zimbabwe' and 'us' allows him, in the words of Wieczorek (2009: 126), 'to communicate [a] sense of unity and belongingness to the addressees as opposed to exclusion of political actors bearing responsibility' for colonial imperialism and racial subjugation. Throughout Mugabe's speech, there is constant polarisation of democracy-freedom and inequality-suppression in the axiological dimension. At the same time, despite the sovereignty of African nations, the West is construed as still lurking on the outside of the axiological axis as illustrated in excerpt (3).

Mugabe address 26/09/2007 - Paragraph 12

The West still negates our sovereignties by way of control of our resources, in the process making us mere chattels in our own lands, mere minders of its trans-national interests. In my own country and other sister states in Southern Africa, the most visible form of control has been over land despoiled from us...

According to Wieczorek (2009: 125), polarisation or distanciation as shown above impacts on the addressees in a number of ways. Amongst other things, polarisation legitimises the actions taken by the speaker. Second, it creates the impression of a highly efficient leader, and third, it constructs discourse elements outside the deictic centre as posing a threat to the addressees. By way of illustration, consider the excerpt below.
Mugabe address 26/09/2007 - Paragraph 13
That control [British colonialism] largely persists, although it stands firmly challenged in Zimbabwe, thereby triggering the current stand-off between us and Britain, supported by her cousin states, most notably the United States and Australia. Mr Bush, Mr Blair and now Mr Brown's sense of human rights precludes our people's right to their God-given resources, which in their view must be controlled by their kith and kin. I am termed dictator because I have rejected this supremacist view and frustrated the neo-colonialists.

Briefly, through the use of 'in Zimbabwe' and 'us' along the spatial axis, Mugabe places himself and fellow Zimbabweans inside the deictic centre, whilst 'Britain', 'her cousin states' ('the United States and Australia'), and their leaders are positioned outside the centre. This positioning of discourse elements not only establishes polarisation between Zimbabweans and Westerners, but also highlights the threat the latter holds for the former in the shape of what Mugabe refers to as their 'supremacist view' of wanting to control Zimbabwe's 'God-givenresources'. This threat serves to justify (or legitimise) Mugabe's actions of having 'rejected this supremacist view and frustrated the neo-colonialists'. Moreover, by carrying out these actions, Mugabe portrays himself not as a dictator (which is the view the West holds of him), but as Zimbabwe's saviour and therefore as 'a competent, efficient and powerful leader' (Wieczorek, 2009: 125).

In his study of legitimisation in political discourse, Cap (2008: 23) argues that politicians employ a number of strategies to enhance their credibility, and one of these is through the use of assertions. Excerpt (4) contains an assertion which, according to Cap (2008: 23), may serve to endorse the speaker's credibility 'by...referring to [an action which is] undeniably logical, legitimate and expected by the addressee, yet difficult to verify at the moment of speaking' - 
'I have rejected this supremacist view and frustrated the neo-colonialists'. Another obvious example of the use of a series of assertions by Mugabe is reflected in the next example.

Mugabe address 26/09/2007 - Paragraph 14

$\rightarrow \quad$ Clearly the history of the struggle for our own national and people's rights is unknown to the president of the United States of America [President Bush].

$\rightarrow \quad$ He thinks the Declaration of Human Rights starts with his last term of office!

$\rightarrow \quad$ He thinks she can introduce to us, who bore the brunt of fighting for the freedoms of our peoples, the virtues of the Universal Declaration of Human Rights...

Here, Mugabe makes a number of assertions to express his belief that the former president of the USA, George W. Bush, is ignorant, not only about human rights, but also about Zimbabwe's protracted struggle for sovereignty. Because Mugabe and Zimbabwean citizens share common ground (i.e., a 'history of the struggle for our own national and people's rights'), 'mental closeness' (Cap, 2005: 25) is established between them. According to Wieczorek (2008: 36), 'the aura of common ground and partnership' between the discourse parties 'allows the speaker to expect that the audience will share her/his point of view, at least to some extent'.

In addition to the use of assertions, a politician may also regularly (a) boast about his or her actions/performance, (b) blame an adversary for a specific state of affairs, or (c) highlight an adversary's lack of moral character in order to achieve common ground with his/her coparticipants (cf. Wieczorek, 2008: 32). These strategies are illustrated in excerpts (6), (7), and (8), respectively, in which Mugabe (a) sings the praises of Zimbabweans for their treatment of Ian Smith, (b) holds Britain and the USA responsible for weakening and maligning Zimbabwe, and (c) accuses George W. Bush of murder in Iraq and Afghanistan.

Mugabe address 26/09/2007 - Paragraph 15

$\rightarrow \quad$ We [Mugabe and fellow Zimbabweans] taught him [Ian Smith] democracy.

$\rightarrow \quad$ We gave him back his humanity...

(7) Mugabe address 26/09/2007 - Paragraph 26

$\rightarrow \quad$ The British and the Americans have gone on a relentless campaign of destabilising and vilifying my country...

Mugabe address 26/09/2007 - Paragraph 21

$\rightarrow \quad$ He [President Bush of the USA] kills in Iraq.

$\rightarrow \quad$ He kills in Afghanistan.

$\rightarrow \quad$ And this is supposed to be our master on human rights?

\subsection{Categorisation}

If we take a look at Mugabe's speech from the perspective of MCA, then it becomes evident that it contains a number of pronouns that do not simply perform a co-referential function, but also achieve social categorisation.

$$
\text { Mugabe address 26/09/2007 - Paragraphs 26-27 }
$$


The British and the Americans have gone on a relentless campaign of destabilising and vilifying my country. They have sponsored surrogate forces to challenge lawful authority in my country. They seek regime change, placing themselves in the role of the Zimbabwean people in whose collective will democracy places the right to define and change regimes.

Let these sinister governments be told here and now that Zimbabwe will not allow a regime change authored by outsiders. We do not interfere with their own systems in America and Britain. Mr Bush and Mr Brown have no role to play in our national affairs...

From the outset, Mugabe constructs membership categorisation devices or category pairs to establish us-them territories: The pronouns 'they' (i.e., 'the British and the Americans') and 'their (own systems)' stand in opposition to 'my (country)', 'we', and 'our', which display Mugabe's orientation to his co-participants, Zimbabwean nationals. By portraying the British and the Americans as having defamed Zimbabwe and undermined its sovereignty, Mugabe implies that America and Britain are the perpetrators of an attack on democracy, while Zimbabwe is the victim of that attack. We therefore have two category pairs in operation here - 'us'/'them' and 'the attacked'/'the attacker' (cf. Leudar et al., 2004: 246). With regard to the former pair, the 'us'/'them' distinction is explicit in Mugabe's use of the words 'Zimbabwe' and 'the British and the Americans'. As far as the latter pair is concerned, the attackers are associated with 'a relentless campaign of destabilising and vilifying' Zimbabwe, '[sponsoring] surrogate forces to challenge lawful authority', and '[seeking] regime change'. By contrast, the attacked - Zimbabweans - are identified as victims of these actions and as upholders of democracy - 'We do not interfere with their own systems in America and Britain'. Since 'they' entail 'sinister governments' who have allegedly attempted to interfere with Zimbabwe's freedom by trying to overthrow Mugabe's 'lawful authority', we can conclude that the category pairs just identified constitute moral, social, and political distinctions. That is, Mugabe employs these category pairs to distinguish Zimbabwe from the West along moral, social, and political lines (Cf. Leudar et al., 2004: 243). Politicians may also polarise groups in religious terms as is the case below.

\section{(10) Mugabe address 26/09/2007 - Paragraphs 13}

... Mr Bush, Mr Blair and now Mr Brown's sense of human rights precludes our people's right to their God-given resources, which in their view must be controlled by their kith and kin. I am termed dictator because I have rejected this supremacist view and frustrated the neo-colonialists.

In this except, the category 'them' includes 'Mr Bush, Mr Blair and...Mr Brown' (i.e., Westerners), whereas 'us' comprises Zimbabweans. Mugabe employs a religious argument to show why both his rejection of Western ideology (a 'supremacist view') and his obstructionist approach to Western leaders ('neo-colonialists') are warranted - 'us' is distinct from 'them' because Mugabe's people have a (divine) 'right to their God-given resources'.

Membership categorisation is not always as straightforward as the above analyses may imply, and this becomes clear in an extract such as the one below. 
We are alarmed that under his [President Bush's] leadership, basic rights of his own people and those of the rest of the world have summarily been rolled back. America is primarily responsible for rewriting core tenets of the Universal Declaration of Human Rights. We seem all guilty for 9/11. Mr. Bush thinks he stands above all structures of governance, whether national or international.

Thus far, the 'us'/'them' distinction has been clear cut in the sense that it has been confined to Zimbabweans and Westerners. However, politicians may choose to extend the membership of a given category for specific reasons (cf. Leudar et al., 2004: 249). In excerpt (11), 'us' is no longer made up of Zimbabweans only, but also of Americans and people around the world whose 'basic rights' have purportedly been taken away by the Bush administration. To paraphrase Leudar et al. (2004: 249), the reason for extending the membership of the category 'us' is to allow Americans and people around the world who regard themselves as victims of Bush's policies to join the category: 'In this way, it can work as an impulse for further development of the dialogical network' (Leudar et al., 2004: 249) or site which, in this case, is the UN General Assembly. Another example is illustrated in the next extract.

\section{(12) Mugabe address 26/09/2007 - Paragraph 13}

We call for the U.N. system to refrain from interfering in matters that are clearly the domain of member states and not a threat to international peace and security. Development at country level should continue to be country-led, and not subject to the whims of powerful donor states.

Once again, the category pair 'us'/'them' operates in the above excerpt, but this time, the category 'them' does not only comprise Western countries ('powerful donor states'), but also the United Nations itself - 'We call for the U.N. system to refrain from interfering in matters that are clearly the domain of member states...'. Mugabe's statement reflects a frequent allegation he has made over the years that the United Nations system is politicised because developed countries have allegedly exploited the UN Security Council for their own gain and at the expense of countries that are economically as well as militarily less powerful.

\subsection{Summary}

To summarise, referring is a phenomenon that enables a politician to achieve inclusion and exclusion of discourse elements in such a way that hearers perceive themselves as being either inside, outside, or on the fringes of the politician's deictic centre which is the convergence of the spatial, temporal, and axiological dimensions. From Mugabe's point of view, Zimbabweans, Africans, and other victims of the West are always insiders, while countries such as Britain, the USA, and Australia are always outsiders.

Having established the typicality of political speeches when it comes to the notion of referring, the next step is to determine how the findings may be exploited to foster Linguistics' students' awareness of the notion and how it is employed to include or exclude discourse parties from the deictic centre. 


\section{TEACHING THE PHENOMENON OF REFERRING WITHIN A MODEL OF CDA}

\subsection{Social, discursive, and textual practices}

How then does one incorporate the principles of CDA into a Linguistics programme aimed at second-year students, particularly when many undergraduates lack critical thinking skills (cf. Avendaño \& Fonseca, 2009: 38)? Following Cots (2006: 336), and in line with constructivism, it is argued that such a programme should '[prioritise] the development of...learners' capacities to examine and judge the world carefully...', and that to this end, CDA should include an examination of the social, discursive, and textual practices reflected in discourse (cf. Fairclough, 1989; 2000). This three-dimensional model, which reflects the principles of CDA, is illustrated in Figure 1 below.

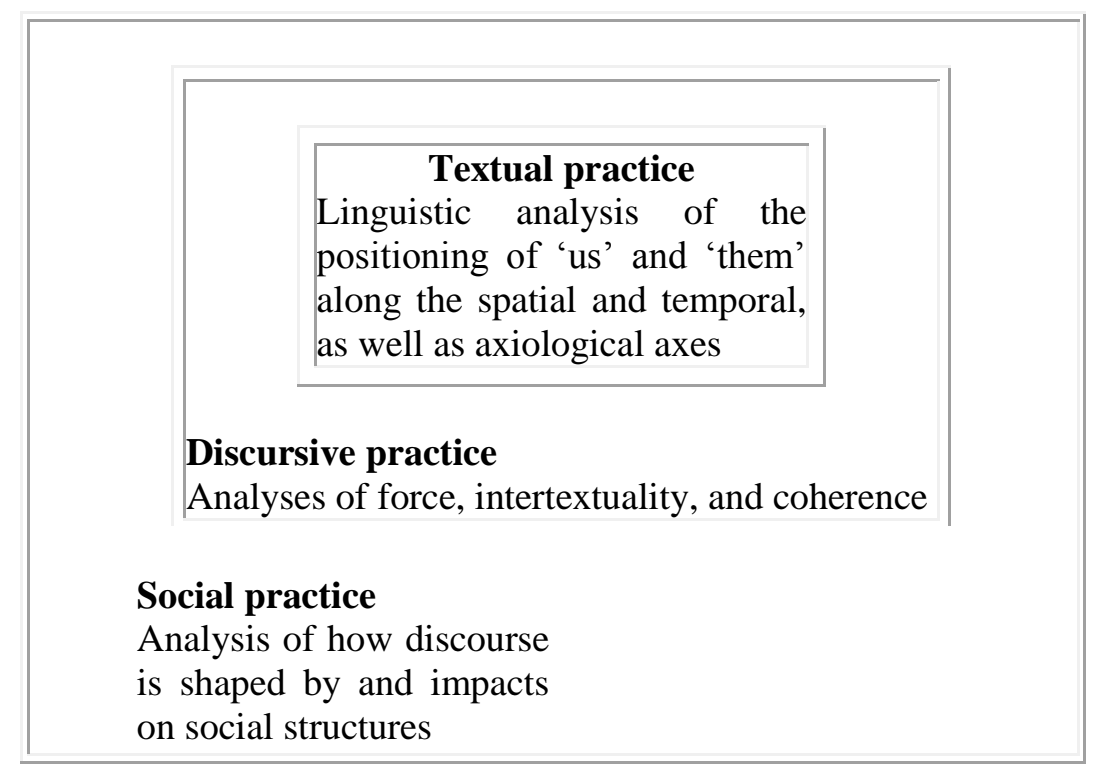

Figure 1. A modified version of Fairclough's (1992: 73) CDA model for students analysing political speeches

If we consider social practice first, then students need to examine the social context of a political speech by taking its discourse setting into account, since each setting has its own unique conventions that dictate what speakers may and may not do. Adopting Halliday's (1985: 12) three aspects of social context, students should reflect on questions such as those below when it comes to analysing a political speech.

Phase 1 - Social practice

1. The field of discourse (ideational meaning): '[What] is it that the [speaker is] engaged in, in which language figures as an essential component?' (Halliday, 1985: 12). In other words, what is the discourse about?

2. The tenor of discourse (interpersonal meaning): Who is participating in the discourse? What is the status and role of each participant? What are the role relationships between the participants? Are you able to identify categories of power and social distance? 
3. The mode of discourse (textual meaning): What is the channel of communication? What is the symbolic organisation of the text? In this regard, is it persuasive or expository, for example?

As far as discursive practice is concerned, students should be made aware of the fact that a text is the product or manifestation of discursive practices. They should therefore be able to answer questions such as those posed below which are essentially based on the three key notions of discursive practice identified by Fairclough (1992: 231-240), namely, force, intertextuality, and coherence.

\section{Phase 2 - Discursive practice}

4. Force: What is the speaker's text used to do socially? (cf. Thornton \& Reynolds, 2006: 274)

5. Intertextual chains: ${ }^{2}$ Does the speaker's text have relations, whether implicit or explicit, to prior/current/potential texts? For example, in his/her text, does the speaker draw on statements from other sources to enhance his/her credibility? Does the speaker rely on particular beliefs or issues he/she knows will be recognisable to the audience? Does the speaker make use of direct or indirect quotations? (cf. Bazerman, 2006: 86-87).

6. Coherence: How do propositions and other rhetorical elements such as lexical and syntactic elements contribute to the overall coherence of the text? Do you have to read between the lines, as it were, in order to make sense of the text?

The third dimension entails textual practice, and here, students are required to consider how specific linguistic features contribute to the production and consumption of a text. For our purposes, students need to focus specifically on the notion of referring and how it is employed by politicians to polarise certain groups of people.

\section{Phase 3 - Textual practice}

7. 'Us' versus 'them' dimensions: Mental representations of ideological beliefs may be expressed in terms of 'us' versus 'them' constructions. Are you able to identify different groups of people in the text? Are these groups presented in positive or negative terms?

8. The deictic centre: How are the various discourse elements, but particularly 'us' and 'them' positioned along the spatial, temporal, and axiological axes?

9. Syntactic structures and lexical choices: Identify the syntactic structures and lexical choices that highlight 'us'/'them' polarisation.

10. Legitimisation and credibility: Identify all the discourse strategies the speaker uses to establish legitimisation and enhance his/her credibility.

\footnotetext{
2 Fairclough (1992: 117) distinguishes between 'manifest intertextuality' and 'constitutive intertextuality' (i.e., interdiscursivity), but here it is suggested that students should work with a more general definition of intertextuality - how one text is related to another.
} 


\subsection{Scaffolding - CDA constructs}

It goes without saying that one cannot simply leave students to their own devices, and expect them to conduct a discourse analysis based solely on the phases outlined above. It is also essential that students be given the opportunity to familiarise themselves with relevant theories within the framework of CDA. This poses quite a challenge to language practitioners as CDA does not stem from a single theoretical framework or methodology (van Dijk, 2000: 353). Besides providing students with a broad introduction to CDA and selected readings on its methodologies and approaches, the author recommends that educators should adopt an approach used by Willett, Ramirez and Correa (2004) together with students at the University of Massachusetts. Willett et al. (2004) required their students to draw on constructs of their choice from CDA and then to (a) conceptualise each construct based on a review of the literature, (b) provide accurate definitions of the constructs, (c) analyse the data they were given in terms of the constructs (once they had contextualised the data), and (d) identify any challenges they experienced when using the constructs. For the purpose of analysing 'us/'them' constructs in political speeches, the author suggests that the following list of constructs be given to students.

\begin{tabular}{|l|l|}
\hline Construct & Literature \\
\hline Agency & Fairclough (2003); Bloome (2005) \\
\hline Axiological axis & Cap (2006, 2008) \\
\hline Clusivity & Cysouw (2005a, 2005b); Filimonova (2005); Adetunji (2006) \\
\hline Coherence & Fairclough (1992) \\
\hline Deictic centre & Chilton (2004) \\
\hline Discursive practice & Fairclough (1992, 2003) \\
\hline Force & Fairclough (1992) \\
\hline Genre & Fairclough (1992) \\
\hline Ideational meaning & Halliday (1985) \\
\hline Identity & Gee (1999); Ribeiro (2006) \\
\hline Ideology & Fairclough (2003) \\
\hline $\begin{array}{l}\text { Interpersonal } \\
\text { meaning }\end{array}$ & Halliday (1985) \\
\hline Intertextuality & Fairclough (1992) \\
\hline Legitimisation & Cap (2005, 2006, 2008) \\
\hline Mediation & Fairclough (2003); Graham (2004) \\
\hline Polarisation & Wieczorek (2009) \\
\hline Power & Fairclough (1992); Bloome (2005) \\
\hline Social practice & Fairclough (1992, 2003) \\
\hline Spatial axis & Cap (2006, 2008) \\
\hline Temporal axis & Cap (2006, 2008) \\
\hline Textual meaning & Halliday (1985) \\
\hline Textual practice & Fairclough (1992, 2003) \\
\hline
\end{tabular}

\subsection{Analysing versus politicising}

Once students are au fait with these constructs and are able to apply them to political speeches, they can move on to MCA and employ this framework in combination with CDA to analyse additional speeches. It is proposed that, in order 'to avoid politicizing, instead of 
analyzing' (Wodak, 2007: 210), students should select diverse political speeches that construct a variety of 'realities' and not only those that reflect a worldview they find objectionable (Poole, 2005: 152), a criticism that has been levelled at some proponents of CDA, most notably, Fairclough (Maral-Hanak, 2009: 190). Of course, the risk of critical bias is also reduced because the approach is one that encompasses triangulation - it encourages students to focus, not only on the linguistic dimension of a politician's discourse, but also on its political and historical dimensions (Wodak, 2006: 9).

\section{CONCLUSION}

There is no doubt that CDA has much to offer language practitioners when it comes to heightening their students' awareness of referring in political discourse and how this notion contributes to establishing specific 'realities'. Future research will involve applying the approach outlined to a second-year Linguistics class to determine its feasibility. Although the approach proposed to teach students how to analyse critically is largely informed by Fairclough's CDA, it is also recommended that students should not adopt his tendency to 'habitually [choose] texts whose underlying assumptions he finds politically distasteful' (Poole, 2010: 152). Instead, students should be encouraged to select different speeches and to look for 'the hidden attitudes and assumptions behind all arguments' (Poole, 2010: 152). In this way, they will avoid premature interpretations before an analysis is even under way.

\section{REFERENCES}

ADETUNJI, A. 2006. Inclusion and exclusion in political discourse: Deixis in Olusegun Obasanjo's speeches. Journal of Language and Linguistics, 5(2):177-191.

AULETTE-ROOT, E. 2010. Khomanani: Critical discourse analysis of South African statefunded publications on HIV. Perspectives on Global Development and Technology, 9(1-2):173-198.

AVENDAÑO, CEM \& MH FONSECA. 2009. Use of discourse analysis to enhance students' critical thinking skills. Zona Próxima, 10:36-49.

BAKER C. 2000. Locating culture in action: Membership categorisation in texts and talk. In Lee, A \& C Poynton (Eds), Culture and text: Discourse and methodology in social research and cultural studies. St Leonarda: Allen and Unwin. 99-113.

BASU, S \& C ROBERTS. 2009. Exploring the role of discourse in undergraduate medical training. Medical Sociology Online, 4(2):35-45.

BAZERMAN, C. 2006. Analyzing the multidimensionality of texts in education. In Green, JL, G Camilli \& PB Elmore (Eds), Handbook on complementary methods in education research. Mahwah, N.J.: Lawrence Erlbaum Associates, Inc. 77-94.

BHATIA, A. 2009. The discourses of terrorism. Journal of Pragmatics, 41:279-289.

BLOOME, D. 2005. Locating microethnographic discourse analysis studies of classroom language and literacy events and the research imagination. In Bloome, D, SP Carter, BM Christian, S Otto \& N Shuart-Faris (Eds), Discourse analysis and the study of classroom language and literacy events: A microethnographic perspective. Mahwah, NJ: Lawrence Erlbaum Associates, Inc. 200-209 
BOTHA, WJ. 2001. The deictic foundation of ideology, with reference to the African Renaissance. In Dirven, R, RM Frank \& C Ilie (Eds), Language and ideology, volume II: Descriptive cognitive approaches. Amsterdam: John Benjamins. 51-76.

BUTLER, CW. 2006. 'No, we're playing families': Membership categorization in children's play. Research on Language and Social Interaction, 39:441-470.

CAP, P. 2005. Language and legitimization: Developments on the proximization model of political discourse analysis. Lodz Papers in Pragmatics, 1:7-36.

CAP, P. 2006. Legitimisation in political discourse: A cross-disciplinary perspective on the modern US war rhetoric. Cambridge: Cambridge Scholars Publishing.

CAP, P. 2008. Towards the proximization model of the analysis of legitimization in political discourse. Journal of Pragmatics, 40:17-41.

CHASE, DR. 2008. Finding hidden meaning in mass media through Critical Discourse Analysis and its implications for language teaching. TESL Working Paper Series, 6(1):37-44.

CHIGONA, W, P MJALI \& N DENZIL. 2007. The role of ICT in national development: A critical discourse analysis of South Africa's government statements. QualIT'07 Qualitative Research in IT, Wellington, New Zealand, 18-23 November, 2007.

CHIGONA, W, M POLLOCK \& JD ROODE. 2009. South Africa's socio-techno divide: A critical discourse analysis of government speeches. SACJ, 44:3-20.

CHILTON, PA. 2004. Analysing political discourse: Theory and practice. London: Routledge.

CHILTON, PA. 2005. Missing links in mainstream CDA: Modules, blends and the critical instinct. In Wodak, R \& PA Chilton (Eds), A new agenda in (critical) discourse analysis: Theory, methodology and interdisciplinarity. Amsterdam: John Benjamins. 19-53.

CHILTON, PA \& C SCHÄFFNER. 2002. Politics as text and talk: Analytic approaches to political discourse. Amsterdam: John Benjamins.

COTS, JM. 2006. Teaching 'with an attitude': Critical Discourse Analysis in EFL teaching. ELT Journal, 60(4):336-345.

CYSOUW, M. 2005a. A typology of honorific uses of clusivity. Typological Studies in Language, 63:213-230.

CYSOUW, M. 2005b. Syncretisms involving clusivity. In Filimonova, E (Ed), Clusivity: typology and case studies of the inclusive-exclusive distinction. Amsterdam: John Benjamins. 73-111.

DE BEAUGRANDE, R. 2006. Critical discourse analysis: History, ideology, methodology. Studies in Language \& Capitalism, 1:29-56.

DIETER, M. 2007. Transformative distance learning: Using critical discourse analysis to understand perspective change in adult asynchronous learners. In Bastiaens, $\mathrm{T} \& \mathrm{~S}$ Carliner (Eds), Proceedings of world conference on e-learning in corporate, government, healthcare, and higher education 2007. Chesapeake, VA: AACE. 24462451. 
EGLIN, P. 2002. Members' gendering work: 'Women', 'feminists' and membership categorization analysis. Discourse \& Society, 13:819-825.

ENSOR, P. 2004. Contesting discourses in higher education curriculum restructuring in South Africa. Higher Education, 48:339-359.

FAIRCLOUGH, N. 1989. Language and power. London: Longman.

FAIRCLOUGH, N. 1992. Discourse and social change. Cambridge: Polity.

FAIRCLOUGH, N. 2000. Language and power. (2 $2^{\text {nd }}$ edition). New York: Longman.

FAIRCLOUGH, N. 2003. Analysing discourse: Textual analysis for social research. London/New York: Routledge.

FAIRCLOUGH, N \& R WODAK. 1997. Critical Discourse Analysis. In van Dijk, TA (Ed), Discourse as social interaction. London: Sage. 258-284.

FILIMONOVA, E (Ed). 2005. Clusivity: Typology and case studies of the inclusive-exclusive distinction. Amsterdam: John Benjamins.

GEE, JP. 1999. An introduction to discourse analysis. New York: Routledge.

GRAHAM, P. 2004. Predication, propagation, and mediation: SFL, CDA, and the inculcation of evaluative meaning systems. In Young, L \& C Harrison (Eds), Systemic functional linguistics and critical discourse analysis. London: Continuum. 53-67

HAIG, E. 2001. A study of the application of critical discourse analysis to ecolinguistics and the teaching of eco-literacy. Studies in Language and Culture, 22(2):205-226.

HALLIDAY, MAK. 1985. Spoken and written language. Oxford: Oxford University Press.

HALLIDAY, MAK \& MIM MATTHIESSEN. 2004. An Introduction to functional grammar. ( $3^{\text {rd }}$ edition). Oxford: Oxford University Press.

HAMMOND, K. 2006. More than a game: A critical discourse analysis of a racial inequality exercise in Japan. TESOL Quarterly, 40(3):545-571.

HANRAHAN, MU. 2005. Highlighting hybridity: A critical discourse analysis of teacher talk in Science classrooms. Science Education, 90(1):8-43.

HART, C. 2008a. Critical discourse analysis and metaphor: Toward a theoretical framework. Critical Discourse Studies, 5(2):91-106.

HART, C. 2008b. Critical discourse analysis and conceptualisation: Mental spaces, blended spaces and discourse spaces. In Hart, C \& D Lukes (Eds), Cognitive linguistics in critical discourse analysis: Application and theory. Cambridge: Cambridge Scholars Press. 106-131.

HENDERSON, R. 2005. A Faircloughian approach to CDA: Principled eclecticism or a method searching for a theory? Melbourne Studies in Education, 46:9-24.

HESTER, S \& P EGLIN. 1997. Culture in action: Studies in membership categorisation analysis. Washington, D.C.: International Institute for Ethnomethodology and Conversation Analysis/University Press of America.

IZADI, F \& H SAGHAYE-BIRIA. 2007. A discourse analysis of elite American newspaper editorials: The case of Iran's nuclear program. Journal of Communication Inquiry, 31(2):140-165. 
JANKS, H. 1999. Critical language awareness, journals, and student identities. Language Awareness, 8(2):111-122.

JOHNSON, GC. 2002. A cautionary tale: A dialogic re-reading of a student teacher's visual reading. Narrative Inquiry, 11(2):451-478.

JOHNSON, GC \& E STEVENS, E. 2002. Moving from the personal to the political in teachers' reflective practice. QJER, 18(1):7-22.

KAPP, R. 2004. 'Reading on the line': An analysis of literacy practices in ESL classes in a South African township school. Language and Education, 18(3):246-263.

LEUDAR, I \& J NEKVAPIL. 2000. Presentations of Romanies in the Czech media: On category work in television debates. Discourse \& Society, 11:487-513.

LEUDAR, I, V MARSLAND \& J NEKVAPIL. 2004. On membership categorization: 'Us', 'them' and 'doing violence' in political discourse. Discourse \& Society, 15(2-3):243266.

MARAL-HANAK, I. 2009. Language, discourse and participation: Studies in donor-driven development in Tanzania. Germany: Lit Verlag.

MEADOWS, B. 2007. Distancing and showing solidarity via metaphor and metonymy in political discourse: A critical study of American statements on Iraq during the years 2004-2005. Critical Approaches to Discourse Analysis across Disciplines (CADAAD), $1(2): 1-17$.

MCINTYRE, D. 2006. Point of view in plays: A cognitive stylistic approach to viewpoint in drama and other text-types. Amsterdam: John Benjamins.

MORGAN, B. 2009. Revitalising the essay in an English for academic purposes course: Critical engagement, multiliteracies and the internet. International Journal of Bilingual Education and Bilingualism, 12(3):309-324.

MOODLEY, G. 2006. Critical analysis of the post-apartheid South African Government's discourse on information and communication technologies (ICTs), poverty and development. Doctoral dissertation. Stellenbosch. University of Stellenbosch.

MOON, C. 2006. Narrating political reconciliation: Truth and reconciliation in South Africa. Social and Legal Studies, 15(2):257-275.

NDAMBUKI, J \& H JANKS. 2010. Political discourses, women's voices: Mismatches in representation. Critical Approaches to Discourse Analysis across Disciplines (CADAAD), 4(1):73-92.

NG'AMBI, D. 2008. A critical discourse analysis of student's anonymous online postings. International Journal of Information and Communication Technology Education, 4(3):40-48.

O'CONNELL, DC \& S KOWAL. 2008. Communicating with one another: Toward a psychology of spontaneous spoken discourse. Springer: New York.

POOLE, B. 2010. Commitment and criticality: Fairclough's critical discourse analysis evaluated. International Journal of Applied Linguistics, 20(2):137-155.

RIBEIRO, B. 2006. Footing, positioning, voice. Are we talking about the same things? In De Fina, A, D Schiffrin \& M Bamberg (Eds), Discourse and identity. Cambridge: Cambridge University Press. 48-82. 
ROGERS, R. 2004. An introduction to critical discourse analysis in education. In Rogers, R (Ed), An introduction to critical discourse analysis. USA: Lawrence Erlbaum Associates, Inc. 1-18.

ROGERS, R. 2008. Critical discourse analysis in education. In Martin-Jones, M, AM de Mejia \& NH Hornberger (Eds), Encyclopedia of language and education, $2^{\text {nd }}$ edition, volume 3: Discourse and education. 53-68.

ROGERS, R \& M MOSLEY. 2006. Racial literacy in a second grade classroom: Critical race theory, whiteness studies, and literacy research. Reading Research Quarterly, 41(4):462-495.

ROGERS, R \& M MOSLEY. 2008. A Critical discourse analysis of racial literacy in teacher education. Linguistics and Education, 19(2):107-131.

ROORYCK, J \& G VANDENWYNGAERD. 2007. The syntax of spatial anaphora. Troms $\phi$ Working Papers on Language \& Linguistics: Nordlyd, 34(2):34-85.

SACKS, H. 1972. An initial investigation of the usability of conversational data for doing sociology. In Sudnow, D. (Ed), Studies in social interaction. New York: The Free Press. 31-74.

SACKS, H. 1992a. Lectures on conversation, Volume I. Oxford: Blackwell.

SACKS, H. 1992b. Lectures on conversation, Volume II. Oxford: Blackwell.

SCHEGLOFF, EA. 2007. Categories in action: Person-reference and membership categorization. Discourse Studies, 9(4):433-461.

STOKOE, EH. 2003. Mothers, single women and sluts: Gender, morality and membership categorisation in neighbour disputes. Feminism and Psychology, 13:317-344.

SUMMERFIELD, T \& A MCHOUL. 2005. Family as a commonsense device and its place in law. International Journal for the Semiotics of Law, 18:243-261.

TANAKA, H. 2006. Emerging English-speaking business discourses in Japan. Journal of Asian Pacific Communication, 16(1):25-50.

Text of President Robert Mugabe's speech at the $62^{\text {nd }}$ Session of the UN General Assembly, 26 September, 2007 [Online]. Available:

http://www.newzimbabwe.com/pages/un34.16973.html: 0-0. [2010, 5 May].

THORNTON, S \& N REYNOLDS. 2006. Analysing classroom interactions using critical discourse analysis. In Novotná, J, H Moraová, M Krátká \& N Stehlíková (Eds), Proceedings $30^{\text {th }}$ conference of the international group for the psychology of mathematics education, volume 5. Prague: Czech Republic. 273-280.

TUPPER, KW. 2008. Drugs, discourses and education: A critical discourse analysis of a high school drug education text. Discourse: Studies in the Cultural Politics of Education, 29(2):223-238.

VAARA, E, V SORSA \& P PÄLLI. 2010. On the force potential of strategy texts: A critical discourse analysis of a strategic plan and its power effects in a city organization. Organization: 1-18.

VAN DIJK, TA. 1984. Prejudice in discourse. Amsterdam: John Benjamins.

VAN DIJK, TA. 1993. Elite discourse and racism. London: Sage. 
VAN DIJK, TA. 2000. Critical discourse analysis [Online]. Available: http://www.discourses.org/OldArticles/Critical\%20discourse\%20analysis.pdf: $\quad 352-$ 371. [2010, 2 September]..

VAN DIJK, TA. 2006. Discourse and manipulation. Discourse \& Society, 17(2):359-383.

WIECZOREK, AE. 2008. Proximisation, common ground, and assertion-based patterns for legitimisation in political discourse. Critical Approaches to Discourse Analysis across Disciplines (CADAAD), 2(1):31-48.

WIECZOREK, AE. 2009. This is to say you're either in or out: Some remarks on clusivity. Critical Approaches to Discourse Analysis across Disciplines (CADAAD), 3(2):118129.

WILLETT, J, A RAMIREZ \& D CORREA, D. 2004. Critical discourse analysis - List of constructs useful in CDA [Online]. Available: http://www.umass.edu/accela/llc/794d/word/syllabus\%20fall05.pdf [2010, 2 September].

WIRGAU, JS, KW FARLEY \& C JENSEN. 2010. Is business discourse colonizing philanthropy? A critical discourse analysis of (PRODUCT) RED. Voluntas: 15737888 .

WODAK, R. (Ed). 1989. Language, power and ideology: Studies in political discourse. Amsterdam: John Benjamins.

WODAK, R. 2001. What CDA is about - a summary of its history, important concepts and its developments. In Wodak, R \& M Meyer (Eds), Methods of critical discourse analysis. London: Sage. 1-13.

WODAK, R. 2006. Images in/and news in a globalised world: Introductory thoughts. In Lassen, I, J Strunk \& T Vestergaard (Eds), Mediating ideology in text and image: Ten critical studies. Amsterdam: John Benjamins. 1-16.

WODAK, R. 2007. Pragmatics and critical discourse analysis: A cross-disciplinary inquiry. Pragmatics \& Cognition, 15(1):203-225.

WODAK, R. 2009. The semiotics of racism: A critical discourse-historical analysis. In Renkema, J (Ed), Discourse, of course: An overview of research in discourse studies. Amsterdam: John Benjamins. 311-326.

ZIMMERMAN, E. 2007. Constructing Korean and Japanese interculturality in talk: Ethnic membership categorization among users of Japanese. Pragmatics, 17(1):71-94.

\section{BIOGRAPHICAL NOTE}

Dr Susan Brokensha is a lecturer in the Department of English, University of the Free State. Dr Brokensha's research focus has always been on discourse analysis and particularly on Critical Discourse Analysis. She has a passion for uncovering the hidden meaning of language, particularly when it comes to exposing the power of language to manipulate or persuade. She has published several articles on institutional discourse. E-mail address: broksha@ufs.ac.za 